\title{
ANALISIS DIVIDEN PAYOUT RATIO DENGAN PENDEKATAN CURRENT RATIO (CR), DEBT TO EQUITY RATIO (DER), RETURN ON INVESTMENT (ROI) PADA PERUSAHAAN BUMN TAHUN 2015-2020
}

\author{
aNi Kadek Ayu Trisnadewi, bNi Wayan Novi Budiasni \\ STIE Satya Dharma singaraja \\ aayu.trisna.22@gmail.com
}

\begin{abstract}
ABSTRAK
Analisis Dividen Payout Ratio Dengan Pendekatan Current Ratio (CR), Debt to Equity Ratio (DER), Return On Investment (ROI) Pada Perusahaan BUMN Tahun 2015-2020. Tujuan penelitian ini berupaya mempelajari beberapa variabel dari $C R, D E R$ dan $R O I$ yang dapat digunakan sebagai alat untuk memprediksi secara singkat dalam penentuan kebijakan deviden. Objek penelitian adalah perusahan BUMN yang di dalamnya termasuk ke periode tahun 2015-2020 dalam penelitian ini. sampel penelitian ini adalah 35 data yaitu 7 perusahaan BUMN yang secara konsisten membayarkan dividen selama 5 tahun dari tahun 2015-2020 dan juga yang ditentukan melalui metode purposive sampling sebanyak 7 perusahaan. Analissi menggunakan metode kuantitatif terhadap laporan keuangan perusahaan BUMN untuk tahun periode 2015-2020 juga akan di lakukan. Hasil anlisis menunjukkan besarnya pengaruh CR terhadap DPR sebesar $15,39 \%$ yang berarti $C R$ berpengaruh sangat rendah terhadap DPR. DER berpengaruh terhadap DPR sebesar 0,45\% ROI terhadap DPR sebesar $61,08 \%$ yang berarti $\mathrm{ROI}$ memiliki pengaruh sangat kuat terhadap DPR.
\end{abstract}

Kata kunci : DPR, CR, DER, ROI

\section{LATAR BELAKANG}

Salah satu jembatan yang bisa di gunakan para pemegang surat berharga perusahaan dalam menyalurkan kesejahteraan masyarakat adalah pasar modal. Dalam pasar modal dividen atau capital gain adalah hasil yang akan di dapatkan oleh pemegang saham. Suatu perusahaan akan menerima besarnya nilai dividen tergantung dari kebijakan deviden dan jumlah keuntungan perusahaan itu sendiri. Dalam pendistribusian laba yang akan didapatkan oleh pemegang saham yaitu berupa dividen maka kebijakan yang sangat berperan penting bagi manajer keuangan adalah kebijakan deviden, (Arifanto,2017). Tujuan di tanamkannya dana oleh para investor ke dalam suuatu perusahaan adalah agar para investor mendapatkan pengembalian investasi entah itu berupa deviden maupun pendapatan dari selisih harga jual saham tersebut terhadap harga belinya.Pembagian dividen yang di inginkan oelh para investor pada umumnya adalah pembagian dividen yang relatif stabil.Mengurangi unsur ketidakpastian dalam investasi maka dapat membangun kepercayaan terhadap perusahaan itu sendiri dengan menjaga stabilitas dividen perusahaan itu sendiri (Risaptoko, 2017).

Pembagian deviden yang relatif stabil selalu di inginkan oleh para investor karena kepercayaan bagi para investor di lihat dari stabilitas deviden terhadap perusahaan itu sendiri.Selain itu juga dapat mengurangi keraguan investor dalam menanamkan dananya kedalam perusahaan. Menahan sebagian laba perusahaan untuk melakukan reinvestasi dalam pembagian deviden kemungkinan akan lebih menguntungkan. Beberapa pertimbangan yang harus di perhatiakan berkaitan dengan pembagain deviden di antaranya untuk kebutuhan dana perusahaan, likuiditas perusahaan, sifat pemegang saham, tujuan tertentu yang berhubungan dengan pembayaran deviden serta faktor lain yang berkaitan dengan kebijakan deviden suatu perusahaan (Rahmawati, 2019)

Rahmawati (2019) menyatakan ketertarikan para investor untuk menanamkan 
dananya di pasar modal salah satu penyebabnya adalah deviden. Saat ini deviden lebih di sukai para investor daripada keuntungasn modal. Salah satu penyebabnya adlah kalau di lihat dari segi pendapatan mereka menganggap bahwa penerimaan dari deviden di bandingakn dengan keuntungan modal lebih besar dan berharga nantinya di kemudian hari. Bagi para investor yang di gunakan untuk mengetahui tentang bagaimana kinerja perusahaan adalah perubahan devidennya. Informasi yang di miliki oelh para investor sangatlah terbatas dalam suatu pasar modal, sehingga pengumuman devidenlah yang akan di gunakan untuk menaikkan harga saham.

Menurut Kurniadi (2010) menyatakan bahwa berkaitan dengan pembayaran deviden yang di lakukan oleh perusahaan maka perusahaan harus bisa menentukan apakah sebagian keuntungan perusahaan yang akan digunakan untuk membayar deviden atau sebaliknya sebagai laba di tahan.Berdasarkan hal tersebut maka sangat penting perusahaan memperthatikan dari segi emiten. Apabila adanya dana internal yang dimiliki perusahaan turun hal ini mungkin di sebabkan karena deviden yang di bagikan sebagai proporsi laba atau keuntungan lebih besar dari laba ditahan.oleh karena itu maka perusahaan perlu mencari dana dari luar perusahaan bila perusahaan ingin melakukan ekspansi.

Dalam menentukan pembagian pendapatan yang akan di bayarkan sebagai deviden kepada pemegang saham maka perlu memiliki kebijaksanaan deviden yang sudah di tetapkan oleh perusahaan. Hal ini akan di pakai sebagai kepentingan informasi oleh pemegang saham, kreditor, maupun pihak eksternal lain yang memiliki kepentingan atas informasi yang dikeluarkan nantinya oleh perusahaan. Dengan kebijakan deviden ini perusahaan akan memberikan sebagian Net profitsecara tunai kepada pemegang saham. Mengingat hal ini sangatlah penting di lakukan dengan tujuan untuk meningkatkan kesejahteraan pemegang saham terutama pemegang saham yang berinvestasi dalam jangka panjang dan bukan pemegang saham yang berorientasi hanya sebatas mencari keuntungan modal saja (capital gain) (Rahmawati, 2019).

Dalam menentukan kebijakan deviden ditentukan oleh beberapa faktor diantaranya adalah tingkat likuiditas, tingkat keuntungan yang diperoleh perusahaan berdasarkan investasi, tingkat perbandingan antara hutang dan modal perusahaan. Besarnya nilai curent ratio di dapatkan dari nilai likuiditas perusahaan dapat dilihat dariyang didapatkan oleh perusahaan, tingkat profit perusahaan dari investasi dapat diketahui dari nilai return on investment $(\mathrm{ROI})$ dan perbandingan hutang tarhadap modal diketahui dari nilai ratio hutang terhadap ekuitas atau debt to equity ratio (Wiagustini,2018). Setiawan (2017) menyatakan bahwa rasio yang membandingkan aktiva lancar dengan kewajiban lancar adalah current ratio. Pada ratio ini jika rasio lancarnya melebihi satu maka artinya perusahaan itu likuid. Semakin tinggi rasio lancarnya maka kemampuan perusahaan akan semakin tinngi juga dalam kaitannya membayar kewajiban perusahaan dan membayar deviden.

CR memiliki pengaruh terhadap DPR sebesar nilai koefesien $14,2 \%$. Penelitian ini dikuatkan juga dari penelitian yang di lakukan oleh Wicaksana (2012) di mana hasil ini menyatakan bahwa CR berpengaruh sebesar $26,7 \%$ pada ratio DPR (Setiawati, 2018). Selain $\mathrm{CR}$,rasio keuangan yang mempengaruhi $D P R$ dalah $D E R$ dan ROI. yang dijadikan jaminan untuk keseluruhan hutangnya adalah setiap rupiah modal sendiri dapat di lihat dari ratio $D E R$ ). Keuntungan yang di perolehnya akan di prioritaskan untuk membayar kewajiban perusahaan sedangkan akan dibagikan sisanya sebagai keuntungan dividen. Sehingga ini yang membuat DER sangat penting pengaruhnya di dalam pembagian dividen perusahaan di kemudian hari (Setiawan, 2017).

Selain hal tersebut di atas maka teori yang menyatakan bahwa DER berpengaruh negatif terhadap DPR sebesar $76 \%$. Teori ini juga di perkuat lagi dari penelitian yang telah di lakukan oleh Kurniawan (2017). Penilaian yang tepat di lakukan untuk menilai sejauh mana tingkat pengembalian yang akan didapat dari aktivitas investasinya salah satu caranya adalah dengan menghitung ROI (Return on Investmen). Dalam hal ini para investor mempunyai keinginan pengembalian untuk investasinya.Apabila perusahaan memiliki keuntungan setiap tahun maka para investor akan memiliki keyakinan atas pengembalian investasi yang akan di perolehnya begitu juga sebaliknya apabila perusahaan pada tahun terakhir tidak mendapatkan keuntungan maka sudah barang tentu terbayang kerugian yang akan di 
dapatkannya ((Hardimugroho, 2017). Pengaruh sebesar 67\% ROI terhadap DPR.ini adalah penelitian yang di lakukan oleh Arilaha (2019). Yang kemudian dikuatkan lagi oleh penelitian yang lakukan Purwanti (2019) di mana dikatakan bahwa ROI mempunyai pengaruh sebesar $29,8 \%$ terhadap DPR.

\section{KAJIAN LITERATUR}

\section{Keterkaitan CR terhadap DPR}

Kasmir (2018) menyatakan bahwa Perusahaan dalam membayar kewajiban jangka pendeknya atau hutang yang akan jatuh tempo akan menngunakan rasio lancar atau current ratio yang mana fungsi dari rasio ini di gunakan adalah untuk mengukur kemampuan perusahaan dalam melunasi semua kewajiban jangka pendeknya. Disebutkan pula bahwa semakin tinggi kemampuan perusahaan dalam menutupi kewajiban jangka pendeknya dapat kita lihat dari semakin besarnya perbandingan aktiva lancar dengan hutang lancar maka akan

Wiagustini $(2018 ; 257)$ menyebutkan bahwa DPR adalah salah satu faktor yang mempengaruhi rasio likuiditasnya. Penelitian yang dilakukan oleh Wicaksana (2018) dapat memperkuat hal tersebut di atas di mana di nyatakan bahwa CR berpengaruh positif dan signifikan terhadap DPR (Dividen Payout). Di peroleh hasil yang sama pula dari penelitian yang di lakukan oleh Widiyanti (2015) di sebutkan dari penelitiannyan yaitu $C R$ berpengaruh positif signifikan terhadap $D P R$ yang berarti dari nilai $C R$ yang semakin tinggi maka akan menyebabkan nilai $D P R$ yang akan diberikan semakin besar.

\section{Hubungan Debt to equity ratio terhadap DPR}

Kasmir (2015) menyatakan bahwa dari hasil penelitian yang di lakukannya di sebutkan bahwa untuk mengukur seberapa besar kegiatan operasi perusahaan dibiayai oleh ekuitasnya di gunakan rasio levarge. salah satu ratio yang di gunakan adalah rasio DER Hal ini dapat juga di lihat dari seberapa besar perusahaan tergantung atas dana para kreditur dibandingkan ketersediaan dana yang di miliki oleh pemilik perusahaan.

Di katakan bahwa DER memiliki pengaruh negatif dan signifikan terhadap $D P R$, ini adalah hasil dari penelitian yang di lakukan Wicaksana (2017). Penelitian yang sama juga yang di lakukan oleh Handayani(2018)dan hasil yang sama juga dari penelitian Kurniawan(2017) dalam penelitian ini di nyatakan DER terhadap DPR berpengaruh secara negatif dan signifikan, di mana arah koefisien nagatif dapat memberikan penjelasan bahwa adanya peningkatan DER akan mengakibatkan penurunan pada Debt to Equity ratio.

\section{Hubungan ROI terhadap Devidend Payout Ratio}

Pertumbuhan profitabilitas perusahaan merupakan indikator penting yang di gunakan di masa yang akan datang untuk menilai prospek perusahaan yang di lakukan oleh para calon investor. Dalam hal ini penting sekali di perhatikan untuk melihat sampai sejauh mana perusahan mampu memberikan pengembalian berdasarkan atas jumlah investasi yang akan ditanamkan para penanam modal dalam perusahaan. Menurut Widiyanti (2015) mengatakan bahwa salah satu rasio yang sering digunakan untuk menghitung kinerja suatu perusahaan adalah ROI. Hasil investasi pada saat ini, hasil investasi di masa lampau, hasil investasi di masa depan dapat di lihat dari hasil analisis $R O I$. Secara umum $R O I$ dinyatakan bukan nilai dari sistem desimal tetapi di nyatakan berdasarkan persentase. Di katakan kondisi suatu perusahaan akan baik jika semakin tinggi ROI (Syamsudin 2019:63).

Pengelolaan asset dikatakan semakin tepat penggunaannya apabila Return on Investmen (ROI) yang tinggi. Hermin (2015) mengungkapkan laba di dapatkan dari selisih antara pendapatan dan keutungan. Laba yang di dapatkan oleh suatu perusahaan dan di bagi dan di tahan sebagai deviden. Hal ini meneyebabkan keuntungan bersih suatu perusahaan akan dapat meningkatkan pengembalian investasi yaitu pendapatan deviden bagi para investor perusahaan. ROI berpengaruh positif signifikan terhadap DPR. Terlihat juga dari hasil penelitian yang di lakukan oleh Arilaha (2019)dan di perkuat penelitian Purwati (2019) dan Widiyanti(2015) yang melakukan penelitian yang sama. Dinyatakan dari hasil penelitian ini adalah berpengaruh ROI terhadap DPR positif signifikan.Sehingga dapat di jelaksan bahwa arah koefisien positif menandakan adanya peningkatan nilai ROI yang akan mampu 
meningkatkan nilai DPR

\section{METODOLOGI PENELITIAN}

Penelitian ini dilakukan di Bursa Efek Idonesia dengan mengambil kelompok perusahaan BUMN yang go public di BEI dan juga kelompok perusahaan yang membayarkan dividen selama 5 tahun. ada 20 perusahaan yang termasuk dalam kategori ini. Populasi dalam penelitian ini di lakukan dengan cara mengambil data time series perusahaan BUMN selama 5 tahun yaitu sebanyak 100 data. Metode purposive sampling yang di gunakan dalam pengambilan sample. Data keuangan perusahaan BUMN yang go public di BEI dan perusahaan yang membayarkan dividen terbesar merupakan kriteria sampel dalam penelitian ini. Sebanyak 7 perusahaan BUMN yang membayarkan dividen terbesar. Di lakuakn penggabungan data time series dan cross section sehingga di peroleh sampel sebanyak $7 \mathrm{x}$ 5 = 35 data. Data kuantitaif dan data kualitatif merupakan jenis data dalam penelitian ini sedangkan data sekunder merupakan sumber data yang di pakai dalam peneltian ini. Teknik dokumentasi di pakai penelitian ini untuk pengumpulan datanya.

\section{HASIL DAN PEMBAHASAN}

Secara bersama-sama antara CR, DER dan ROI terhadap DPR dengan nilai probability $0,000<$ tingkat kepercayaan $5 \%$. Selain itu ditunjukkan juga bahwa CR, DER dan ROI memiliki pengaruh yang cukup tinggi terhadap DPR. dikarenakan nilai tersebut mendekati nilai satu. Hal ini dapat di lihat dari hasil penelitian ini yaitu sebesar 0,9463 yang berasal koefisien determinasi.untuk dividen payout ratio $94,63 \%$ dipengaruhi oleh variasi variabel yang digunakan di antaranya yaitu $\mathrm{CR}$, DER , dan ROI, sebanyak 5,37\% sisanya tidak masuk dalam penelitian ini karena dipengaruhi oleh faktor lain. Secara parsial $D P R$ berpengaruh positif dan signifikan terhadap variabel $C R$ dan variabel $R O I$ sedangkan berpengaruh negatif variabel $D E R$ terhadap $D E R$. Secara terperinci pengaruh masing-masing variabel diuraikan seperti berikut ini.

\section{CR terhadap DPR}

Diketahui nilai correlations dari $C R$ terhadap DPR sebesar $15,39 \%$ di lihat dari hasil penelitian diatas. Hal ini berarti ada pengaruh yang sangat rendah yang di tunjukkan dari $C R$ terhadap DPR. sebesar 2,305488 nilai T statistik dari $C R$ nilai ini lebih besar 0,324 dari nilai t tabel sebesar dan sebesar 0,0297 nilai probability $C R$. Sebesar $5 \%$ tingkat kepercayaan yang di miliki. Hal ini dapat juga kita lihat dari nilai coefficient dari Current Ratio (CR) adalah sebesar 0,180731.

Sehingga dari hasil perhitungan tersebut diatas dapat dibuat persamaan $D P R=$ Standardized Coefficients $C R$ (DPR $=0,423 \mathrm{CR}$ ) yang menyatakan bahwa 1 satuan kenaikan dari $C R$, maka sebesar 0,411 DPR juga akan mengalami kenaikan.Di lihat nilai probability 0,0297 dengan tingkat kepercayaan 5\% yang berarti dari nilai T statistik yang lebih besar daripada $T$ tabel maka artinya bahwa memiliki pengaruh yang positif dan signifikan $C R$ terhadap Dividen DPR.

Pengujian hipotesis pertama $(\mathrm{H} 1)$ yang diperoleh hasil dalam penelitian ini bahwa dengan nilai $C R$ yang semakin tinggi maka akan semakin tinggi juga Dividen Payout Ratio perusahaan BUMN diterima. Widiyanti (2017) dan Setiawati (2018) sebelumnya melakukan penelitian yang hasilnya menguatkan hasil penelitian tersebut di atas yaitu sama-sama mendapatkan hasil bahwa pengaruh Currennt Ratio $(C R)$ terhadap DPR adalah positif dan signifikan yang berarti bahwa apabila mengalami peningkatan nilai $C R$ maka $D P R$ juga akan ikut mengalami peningkatan.

\section{DER terhadap DPR}

Pengaruh yang di miliki DER sangat rendah pada $D P R$. Hal ini di sebabkan karena nilai correlations dari $D R E$ terhadap $D P R$ sebesar 0,45\%.Sebesar $-2,184400$ nilai T statistik dari $D E R$. Artinya adalah nilai t tabel sebesar 0,324 lebih besar dari nilai probability $D E R$ 
adalah 0,0385 sebesar 5\% sebagai tingkat kepercayaan Bisa kita lihat juga dari Nilai coefficient dari DER adalah sebesar -0,013949.

Dari hasil perhitungan tersebut diatas dapat dibuat persamaan $D P R=$ Standardized Coefficients $C R(\mathrm{DPR}=-0,156 \mathrm{CR}$ ) yang menyatakan bahwa 1 satuan kenaikan dari $D E R$ , maka sebesar $0.158 D P R$ akan mengalami penurunan.Di lihat nilai probability 0,0385 dengan tingkat kepercayaan $5 \%$ yang berarti dari nilai T statistik yang lebih besar daripada $T$ tabel maka artinya bahwa memiliki pengaruh negatif dan signifikan $C R$ terhadap Dividen DPR.

Nilai $D E R$ sangat besar hutang yang di miliki perusahaan. Di perkirakan sebagian besar modal yang dimiliki perusahaan akan di gunakan sebagai jaminan hutang perusahaan hal seperti inilah yang membuat perusahaan nanyinya akan kesulitan mendapatkan keuntungan besar. Di nyatakan bahwa untuk hipotesis kedua $(\mathrm{H} 2)$ yang diperoleh hasil dalam penelitian ini bahwa dengan nilai $D E R$ yang tinggi bisa menurunkan nilai DPR.sehingga hipotesisnya adalah semakin tinggi $D E R$ maka akan semakin rendah $D P R$ perusahaan BUMN diterima

Wicaksana (2018) dan Handayani (2015) sebelumnya melakukan penelitian yang hasilnya menguatkan hasil penelitian tersebut di atas yaitu sama-sama mendapatkan hasil bahwa pengaruh $D E R$ terhadap $D P R$ adalah negatif dan signifikan yang berarti bahwa apabila mengalami peningkatan nilai $D E R$ maka $D P R$ juga tidak ikut mengalami peningkatan.

\section{ROI terhadap DPR}

Pengaruh yang di miliki ROI sangat kuat pada $D P R$. Hal ini di sebabkan karena nilai correlations dari DRE terhadap DPR sebesar $161,08 \%$.Sebesar 6,176163 nilai T statistik dari $D E R$. Artinya adalah nilai t tabel sebesar 0,324 lebih besar dari nilai probability $D E R$ adalah 0,000 sebesar 5\% sebagai tingkat kepercayaan Bisa kita lihat juga dari Nilai coefficient dari $D E R$ adalah sebesar 0,640867. Dari hasil perhitungan tersebut diatas dapat dibuat persamaan $D P R=$ Standardized Coefficients ROI $(\mathrm{DPR}=2.007 \mathrm{ROI})$ yang menyatakan bahwa 1 satuan kenaikan dari $R O I$, maka sebesar $2.041 \mathrm{ROI}$ akan mengalami kenaikan.Di lihat nilai probability 0,000 dengan tingkat kepercayaan $5 \%$ yang berarti dari nilai T statistik yang lebih besar daripada $T$ tabel maka artinya bahwa memiliki pengaruh positif dan signifikan $R O I$ terhadap $D P R$.

Pengujian hipotesis ketiga $(\mathrm{H} 3)$ yang diperoleh hasil dalam penelitian ini bahwa dengan nilai $R O$ l yang tinggi bisa menurunkan nilai DPR.sehingga hipotesisnya adalah semakin tinggi $R O I$ maka akan semakin tinggi $D P R$ perusahaan BUMN diterima. Arilaha (2017) dan Purwanti (2019) sebelumnya melakukan penelitian yang hasilnya menguatkan hasil penelitian tersebut di atas yaitu sama-sama mendapatkan hasil bahwa pengaruh $R O I$ terhadap $D P R$ adalah positif dan signifikan yang berarti bahwa apabila mengalami peningkatan nilai $\mathrm{ROI}$ maka $D P R$ juga tidak ikut mengalami peningkatan. $C R, D E R$ dan $R O I$ secara bersama-sama memiliki pengaruh terhadap $D P R$ sebesar 0,000 . nilai probability dan tingkat kepercayaan $5 \%$.

Hasil dalam penelitian tersebut di atas di peroleh bahwa $C R, D E R$, Dan ROI cukup tinggi pengaruhnya terhadap $D P R$ dikarenakan nilai tersebut mendekati nilai 1 (satu). artinya sebesar $94,63 \% D P R$ dipengaruhi oleh variasi variabel yang digunakan yaitu $C R, D R$ dan $R O I$. Sebesar $5,37 \%$ tidak masuk dalam penelitian ini karena merupakan variabel yang dipengaruhi oleh faktor lain. sebesar 0,9463 nilai koefisien determinasi dari penelitian ini.

\section{KESIMPULAN DAN SARAN}

\section{Simpulan}

Dari penelitian yang telah dilakukan hingga di dapatkan suatu hasil, maka dapat di simpulkan beberapa hal sebagai berikut : 
1. Adanya pengaruh positif dan signifikan dari $C R$ terhadap $D P R$. DPR perusahaan BUMN akan semakin meningkat di sebabkan karena nilai Current Ratio semakin tinggi.. Dapat di lihat sebesar 0,180731 dari nilai koefisien Current Ratio (CR). Sebesar 2,305488 nilai T statistik ,sebesar 0,0297 nilai probability dan 5\% tingkat kepercayaan. Sangat rendah nilai $C R$ pengaruhnya terhadap $D P R$ di lihat dari besarnya pengaruh nilai $C R$ terhadap $D P R$ dengan nilai Correlations yang di miliki sebesar 15,39\%.

2. $D E R$ memiliki pengaruh negatif dan signifikan terhadap $D P R$ yang berarti nilai $D E R$ yang semakin tinggi maka $D P R$ perusahaan BUMN akan semakin rendah. Dapat di lihat bahwa koefisien $D E R$ adalah sebesar -0,013949 yang mana sebesar -2,184400 dari T statistiknya dan 0,0385 nilai probability dengan tingkat kepercayaan $5 \%$. Dapat di nyatakan bahwa hal tersebut mempengaruhi besarnya nilai $D E R$ terhadap DPR sebesar $0,45 \%$ berdasarkan nilai Correlations yang berarti bahwa DER sangat rendah pengaruhnya terhadap DPR.

3. memiliki pengaruh positif dan signifikan $R O I$ terhadap $D E R$ yang artinya bahwa semakin tinggi nilai Return On Invesment (ROI) suatu perusahaan maka DPR perusahaan BUMN semakin meningkat. nilai koefisien sebesar 0,640867 pada $R O I$. sebesar 6,106163 nilai T statistik adalah yang di dapatkan dari perhitungannya,sebesar 0,000 nilai probability sebsar $5 \%$ nilai dari dengan tingkat kepercayaan.

4. Dengan perhitungan di atas maka dapat di nyatakan bahwa besarnya pengaruh nilai $R O I$ sebesar $161,08 \%$ terhadap DPR dilihat dari nilai Correlations yang berarti bahwa pengaruh $R O I$ sangat kuat terhadap DPR.

\section{Saran}

Setelah di lakukan analisis data sehingga bisa di tarik suatu kesimpulan, ada beberapa saran yang ingin di sampaikan oleh penulis sebagai berikut :

1. Variabel $D P R$ memiliki pengaruh rendah yang dapat ditingkatkan dengan cara meningkatkan jumlah kas agar bisa digunakan untuk membayar hutang jangka pendek dan sisanya dapat dibagikan sebagai deviden tunai kepada para investor.

2. Dengan kecilnya nilai DER maka mampu meningkatkan DPR, untuk lebih meningkatkan Dividen Payout Ratio (DPR) perusahaan harus membatasi jumlah pinjaman perusahaan sehingga laba yang diperoleh dapat dibagikan terhadap investor dibandingkan harus dijadikan laba ditahan untuk operasional perusahaan.

3. Return On Invesment terhadap DPR memiliki pengaruh sangat kuat sehingga perusahaan harus mempertahankan hasil dan investasi yang dilakukan investor agar pembagian deviden bisa konsisten

4. Setelah di lakukan penelitian ini maka diharapkan agar hasil penelitian ini bisa di pakai tambahan referensi untuk penelitian selanjutnya, dan tentunya penelitian di masa mendatang dibidang yang sama agar lebih dikembangkan lagi. misalnya dengan menambah jumlah variabelnya, melakukan penelitian dengan jenis perusahaan yang berbeda,lebih memeperpanjang lagi periode pengamatan yang di lakukan.

\section{REFRENSI}

Arifanto, Nur Imam. 2017. Analisis Pengaruh Agency Cost Terhadapt Dividend Payout Ratio (DPR). Skripsi. Semarang : Universitas Diponegoro.

Arilaha, Muhamad Asril. 2019. Pengaruh Free Cash Flow, Protabilitas, Likuiditas, Dan Leverage Terhadap Kebijakan Dividen. Jurnal Keuangan dan Perbankan Vol 13.

Bursa Efek Jakarta. 2018-2020. Annual Report. http://www.jsx.co.id

Handayani, D.R. dan Hadinugroho, B. 2019. Analisis Pengaruh Kepemilikan Manajerial, Kebijakan Hutang, ROA, Ukuran Perusahaan Terhadap Kebijakan Dividen. Jurnal Fokus Manajerial.

Hardinugroho, Agung. 2017. Analisis Faktor-Faktor Yang Mempengaruhi Dividend Payout Ratio Pada Perusahaan Manufaktur Yang Terdaftar di BEI Tahun 2011-2016. Skripsi. 
Semarang : Universitas Diponegoro Jogiyanto, HM. 2008. Teori Portofolio dan Analisis Investasi. Cetakan Kelima. BPFE- Yogyakarta.

Kasmir. 2018. Analisis Laporan Keuangan. Jakarta

Kasmir. 2015. Analisis Laporan Keuangan. Edisi Satu. Cetakan Keempat. PT.Raja Grafindo Persada, Jakarta

Kurniadi, Rendhi. 2018. Analisis Faktor-Faktor Yang Mempengaruhi Dividen Payout Ratio Pada Perusahaan Manufaktur Yang Terdaftar Di Bursa Efek Indonesia. Skripsi. Jawa Timur : Universitas Pembangunan Nasional

Kurniawan, Iwan. 2017. Variabel-Variabel Yang Mempengaruhi Kebijakan Pembayaran Dividen Pada Perusahaan Industri Otomotif Yang Terdaftar Di Bursa Efek Indonesia.

Purwanti, Dwi. 2019. Dampak Rasio Keuangan Terhadap Kebijakan Dividen (Studi Empiris perusahaan Manufaktur Yang Terdaftar Di Bursa Efek Indonesia Periode 2015-2018). Jurnal Skripsi.

Rahmawati, Eva. 2019. Pengaruh Current Ratio, ROA, Kebijakan Hutang, Dan Ukuran Perusahaan Terhadap Kebijakan Dividen Dengan Menggunakan Regresi Logistik. Skripsi. Jakarta : Universitas Islam Negeri Syarif Hidayatullah

Risaptoko, RB Atok. 2017. Analisis Pengaruh Cash Ratio, Debt To Total Asset, Asset Growth, Firm Size Dan Return On Asset Terhadap Dividen Payout Ratio. Tesis. Semarang : Universitas Diponegoro

Setiawan. 2017 Analisis Faktor-Faktor Yang Mempengaruhi Dividen Per Share (DPS) Pada Perusahaan Manufaktur Yang Terdaftar Di BEI(Periode 2013-2016). Skripsi. Makasar : Universitas Hasanudin.

Syamsudin, Lukman. 2017. Manajemen Keuangan Perusahaan. PT. Raja Grafindo Persada. Jakarta

Wiagustini, Ni Luh Putu. 2018. Dasar-Dasar Manajemen Keuangan. Udayana University Press, Denpasar. Bali.

Wicaksana, I Gede Ananditha. 2018. Pengaruh Cash Ratio, Debt to Equity Ratio, Dan Return on Asset Terhadap Kebijakan Dividen Pada Perusahaan Manufaktur Di Bursa Efek Indonesia. Tesis. Denpasar : Universitas Udayana

Widiyanti, Dian Septi. 2015. Analisis Faktor-Faktor yang mempengaruhi Dividen (Studi Kasus Pada Perusahaan Manufaktur yang Terdaftar Di BEI Tahun2009-2014). 